\title{
Haplosporidium nelsoni and $H$. costale in the Pacific oyster Crassostrea gigas from China's coasts
}

\author{
Zhongwei Wang ${ }^{1,3}$, Xin Lu$^{2}$, Yubo Liang ${ }^{3, *}$, Chunde Wang ${ }^{4}$ \\ ${ }^{1}$ Environmental Science and Engineering College, Dalian Maritime University, Linghai Road No. 1, Dalian 116026, PR China \\ ${ }^{2}$ Life Science and Technology College, Dalian Fisheries University, Heishijiao Street No. 52, Dalian116023, PR China \\ ${ }^{3}$ Marine Environmental and Ecology Department, National Marine Environmental Monitoring Center, Linghe Street No. 42, \\ Dalian 116023, PR China \\ ${ }^{4}$ Animal Science and Technology College, Qingdao Agricultural University, Changcheng Road No. 700, Qingdao 266109, \\ PR China
}

\begin{abstract}
We examined 220 Pacific oysters Crassostrea gigas obtained from 11 locations along China's coasts for the presence of the 2 protistan parasites Haplosporidium nelsoni (MSX; multinucleated sphere $\mathrm{X}$ ) and $H$. costale (SSO; seaside organism). Haplosporidium-like plasmodia were histologically observed in 9 oysters $(4.09 \%$ ) from 7 locations. Five oysters had mixed infections, and 4 oysters were infected only with $H$. nelsoni as determined by in situ hybridization (ISH) and polymerase chain reaction (PCR). This is the first report of $H$. nelsoni and $H$. costale infection in bivalves in Chinese waters.
\end{abstract}

KEY WORDS: Haplosporidium nelsoni $\cdot$ Haplosporidium costale $\cdot$ Parasites $\cdot$ Crassostrea gigas Histology $\cdot$ In situ hybridization · Polymerase chain reaction

\section{INTRODUCTION}

Haplosporidium nelsoni (MSX; multinucleated sphere $\mathrm{X}$ ) and $H$. costale (SSO; seaside organism) are morphologically similar pathogens of the eastern oyster Crassostrea virginica that occur along the east coast of the United States (Stokes \& Burreson 2001). H. nelsoni was first identified in the eastern United States in the spring of 1957 (Haskin et al. 1965). This pathogen was associated with an outbreak that resulted in high mortalities in C. virginica in the Delaware and Chesapeake Bays (Haskin \& Andrews 1988). Recent studies have shown that $H$. nelsoni has been detected in the Pacific oyster C. gigas from different parts of the world, including Japan, Korea, and California (Friedman 1996, Burreson et al. 2000, Kamaishi \& Yoshinaga 2002). H. costale was first reported to cause high mortalities in C. virginica along the Atlantic coast of Virginia in the1960s (Andrews et al. 1962, Wood \& Andrews 1962). Later, Sunila et al. (2002) suggest that $H$. costale was also present in the eastern oysters in
Long Island Sound. The distribution of these 2 pathogens overlaps in some areas; however, the known range of $H$. nelsoni is wider than that of $H$. costale. Although an unidentified haplosporidian parasite has been observed in the bay scallop Argopecten irradians in Shandong and Liaoning Provinces in China by histological methods (Chu et al. 1996), H. nelsoni and $H$. costale have not been reported in any bivalves in China.

The parasites are easy to distinguish if spores are present, based on the locations and sizes of spores (Couch 1967). However, no definitive characteristics have been found with hematoxylin and eosin (H\&E) stain to distinguish Haplosporidium nelsoni and $H$. costale plasmodia (Andrews \& Castagna 1978). The ability to rapidly and accurately detect parasites of oysters has broad implications for both research and industry. The development of molecular tools provides a means to detect the cryptic life stages of similar species and to identify them. Specific polymerase chain reaction (PCR) and in situ hybridization (ISH) have 
been developed for $H$. nelsoni and $H$. costale in recent years (Ko et al. 1995, Stokes et al. 1995, Renault et al. 2000, Stokes \& Burreson 2001).

In the present study, the discovery of haplosporidian plasmodia is reported in Pacific oysters from China's coasts during epizootiological surveys for bivalve pathogens. No spores were found in infected oysters; therefore, DNA-based diagnostics were used to identify mixed plasmodial infections of the 2 species.

\section{MATERIALS AND METHODS}

Sample collection. A total of 20 cultured Pacific oysters Crassostrea gigas were collected for routine histological surveys from 11 locations between April 2006 and January 2008 (Fig. 1, see Table 1). Mean shell length of 20 oysters from each site was recorded (see Table 1).

Light microscopy. Each oyster was processed by removing the digestive gland tissue and cutting it into 2 pieces along the sagittal plane; then half was placed in Bouin's solution and the other half was collected for genomic DNA extraction and subsequent PCR analysis. Samples fixed in Bouin's solution for $24 \mathrm{~h}$ were stored in $70 \%$ alcohol; then the tissues were dehydrated in an ascending series of ethanol solutions and embedded in paraffin, and $5 \mu \mathrm{m}$ sections were stained with H\&E using conventional histological techniques.

ISH. In order to identify these parasites in histological sections, in situ hybridization was performed on Bouin's fixed, paraffin-embedded tissue of the oyster using $2 \mathrm{ng} \mathrm{ul}^{-1}$ of the Haplosporidium nelsoni-specific DNA probe MSX1347 or $5 \mathrm{ng} \mathrm{pl}^{-1} \mathrm{H}$. costale-specific DNA probe SSO1318, as described previously (Stokes \& Burreson 1995). These probes were labeled with digoxigenin at $5^{\prime}$ end by TaKaRa Biotechnology Company. Negative controls contained no probe in the hybridization solution, and uninfected oysters were used. No positive control infected slides such as $\mathrm{H}$. nelsoni and $H$. costale were used for the ISH. The ISH procedure was conducted with negative controls and 9 oysters, which confirmed the presence of haplosporidian-like plasmodia using histology diagnosis. Tissue sections for ISH were processed as described elsewhere (Stokes \& Burreson 1995, 2001).

PCR. Genomic DNA was extracted from the digestive gland tissue for each oyster at each site using QIAamp DNA Mini Kit (Qiagen) and was performed according to the manufacturer's protocol. Haplosporidium nelsonispecific primers MSX-A' and MSX-B (Renault et al. 2000) were used in the PCR. This primer pair can amplify a $573 \mathrm{bp}$ section of the small subunit (SSU) region of the rRNA gene of $H$. nelsoni. The PCR reactions contained 10× PCR buffer $(100 \mathrm{mM}$ Tris- $\mathrm{HCl}, \mathrm{pH} 8.3$, $500 \mathrm{mM} \mathrm{KCl}, 15 \mathrm{mM} \mathrm{MgCl} 2$ ), $2.5 \mathrm{mM}$ each of dATP,
dCTP, dGTP, dTTP, $5 \mathrm{U} \mathrm{ul}^{-1}$ of TaKaRa EX Taq, 20 pmol of each primer, and template DNA in a total volume of $50 \mu \mathrm{l}$. Each of the reaction mixtures was cycled in a PCR System TP240 thermal cycler (TaKaRa BIO.INC). Cycling conditions for PCR began with an initial denaturation of the sample at $94^{\circ} \mathrm{C}$ for $4 \mathrm{~min}$, followed by 34 cycles at $94^{\circ} \mathrm{C}$ for $30 \mathrm{~s}, 59^{\circ} \mathrm{C}$ for $30 \mathrm{~s}, 72^{\circ} \mathrm{C}$ for $1.5 \mathrm{~min}$, and a final extension at $72^{\circ} \mathrm{C}$ for $5 \mathrm{~min}$. The $\mathrm{H}$. costalespecific primers SSO-A and SSO-B (Stokes \& Burreson 2001) and PCR reaction mixtures were prepared and cycled as described for $H$. nelsoni. This primer pair would amplify a $557 \mathrm{bp}$ section of the SSU region of the rRNA gene of $H$. costale. Each PCR product was determined by loading a $6 \mu \mathrm{l}$ aliquot of the PCR products on a $2.0 \%$ agarose gel and electrophoresing it at $200 \mathrm{~V}$ for 30 min. Negative control containing no template DNA in the PCR reaction was used. No positive control DNA from oysters confirmed as containing $H$. nelsoni and H. costale was used.

DNA sequencing. All the PCR products from the PCR-positive samples were ethanol-precipitated, ligated into the plasmid vector PMD18 (TaKaRa), and transformed into JM109 cells by the TaKaRa Biotechnology Company (Dalian). Clones with inserts were cycle sequenced via simultaneous bidirectional sequencing using M13-47 (TaKaRa) forward and reverse

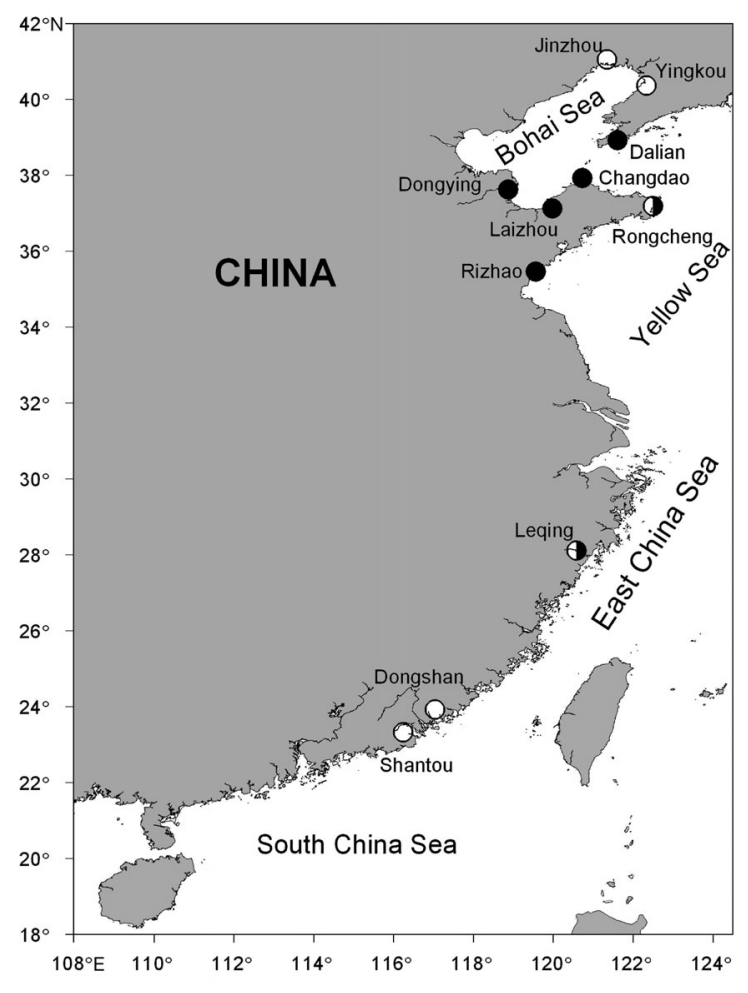

Fig. 1. Sampling locations off China's coasts. (-) Sampling locations with mixed infections with Haplosporidium nelsoni and $H$. costale; $(\mathbf{O})$ sampling locations with $H$. nelsoni only; (O) sampling locations without these 2 protistan infections 
primers labeled using BigDye ${ }^{\circledR}$ Terminator v3.1 Cycle Sequencing Kit (Applied Biosystems). Sequencing reactions were electrophoresed on a POP-7TM (Performance Optimized Polymer; Applied Biosystems) gel in an ABI PRISM ${ }^{\mathrm{TM}}$ 377XL DNA automated sequencer. Sequence data were verified using BLAST searches of the GenBank database.

\section{RESULTS}

\section{Histopathology}

Haplosporidium-like plasmodia were detected in 7 locations on China's coasts: Dalian, Dongying, Laizhou, Changdao, Rongcheng, Rizhao, and Leqing (Table 1). There were 9 oysters with haplosporidiumlike plasmodia among the 220 oysters studied $(4.09 \%)$. Histological examination of stained sections showed the presence of haplosporidium-like plasmodia within the digestive gland of oysters. The infiltration of host hemocytes was also observed. The diameter of the plasmodia was approximately $5 \mu \mathrm{m}$, and numerous nuclei were observed in each plasmodia (Fig. 2). No spores or sporogonic stages were observed.

\section{ISH assays}

Plasmodia in tissues of all 9 oysters hybridized with the MSX1347 probe (Fig. 3A), thus supporting the histological diagnoses. However, some plasmodia in 5 of the 9 oysters also hybridized with the SSO1318 probe
(Fig. 3B). That is to say, 5 oysters had mixed infections, the rest were infected only with Haplosporidium nelsoni. These mixed infections of $H$. nelsoni and $H$. costale were not distinguishable by histological examination because only plasmodia of $H$. nelsoni or a few plasmodia of $H$. costale were present, but they were strongly detected by ISH. Negative controls contained no probe and did not hybridize (Fig. 3C).

\section{PCR assays}

A DNA fragment of $573 \mathrm{bp}$ was amplified using primers MSX-A' and MSX-B in all of the 9 oysters previously diagnosed by histological examination of H\&E-stained paraffin sections (Fig. 4). All of the sequences shared $99 \%$ similarity with the SSU rRNA gene sequence of Haplosporidium nelsoni (GenBank accession no. AB080597). Bases A and $\mathrm{C}$ at positions 805 and 852, respectively, of $H$. nelsoni SSU rRNA were both changed to $\mathrm{G}$ in the present study. The 560 bp product was also easily detected in 5 of the 9 oysters previously diagnosed by histological examination after PCR amplification using SSO-A and SSO-B (Fig. 5). Their sequences were identical to each other and shared 99\% similarity with the SSU rRNA gene partial sequence of H. costale (GenBank accession no. AF387122). In this study, the PCR amplification product size was $560 \mathrm{bp}$ (expected product size: $557 \mathrm{bp}$ ) because of a 3-base insertion (AGC) at positions 1129 to 1132 of $H$. costale SSU rRNA. No DNA fragment of 573 or 557 bp was found in PCR products in other oysters from any of the locations. Thus, we confirmed the identity of the 2 parasites as $H$. nelsoni and $H$. costale by the sequence information.

Table 1. Crassostrea gigas. Histology, in situ hybridization (ISH), and polymerase chain reaction (PCR) results of diagnostic tests for Haplosporidium nelsoni (MSX; multinucleated sphere X) and H. costale (SSO; seaside organism) in Pacific oysters in China. Histology diagnosis recorded as (+) if haplosporidian-like plasmodia were found in the tissues and (-) if no haplosporidian-like plasmodia were found. PCR diagnosis recorded as (+) if the 573 or $557 \mathrm{bp}$ amplification production was present on the agarose gel and (-) if no amplification production was present

\begin{tabular}{|lcccccc|}
\hline Location & Date & $\begin{array}{c}\text { Mean shell } \\
\text { length (mm) }\end{array}$ & $\mathrm{n}$ & Number positive & Histology & ISH \\
\hline Jinzhou & Aug 2007 & 127.2 & 20 & 0 & - & No analysis \\
Yingkou & Aug 2007 & 121.2 & 20 & 0 & - & No analysis \\
Dalian & Apr 2006 & 65.4 & 20 & 1 & + & MSX, SSO \\
Changdao & May 2007 & 88.5 & 20 & 1 & + & MSX, SSO \\
Dongying & Aug 2007 & 85.0 & 20 & 1 & + & MSX, SSO \\
Laizhou & Aug 2007 & 81.5 & 20 & 2 & + & MSX, SSO \\
Rongcheng & Jan 2008 & 98.2 & 20 & 1 & + & MSX \\
Rizhao & Jul 2007 & 77.0 & 20 & 2 & + & MSX, SSO \\
Leqing & Jan 2008 & 89.5 & 20 & 0 & - & MSX \\
Dongshan & Jan 2008 & 59.3 & 20 & 0 & - & No analysis \\
Shantou & Jul 2007 & 77.6 & 20 & & + & + \\
& & & & & & + \\
\hline
\end{tabular}



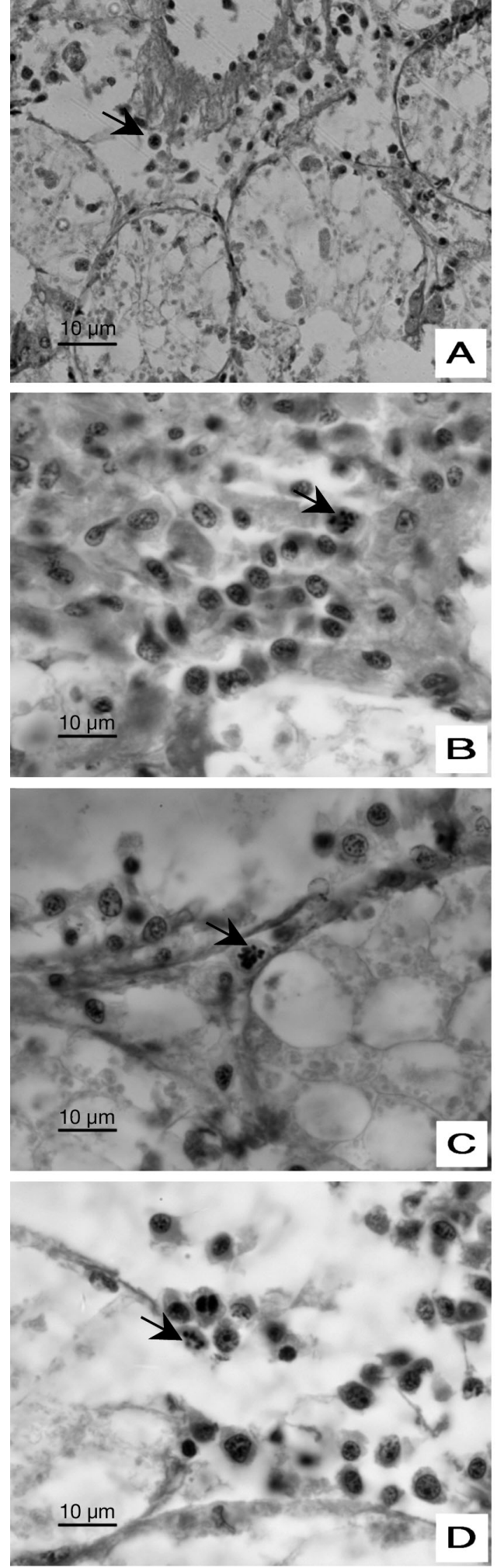

Fig. 2. Crassostrea gigas infected by Haplosporidium spp. Histological observation of haplosporidian multinucleate plasmodia (arrow) in the digestive gland connective tissue of infected oysters collected at (A) Dalian, (B) Dongying, (C) Rizhao, and (D) Leqing. Scale bar $=10 \mu \mathrm{m}$
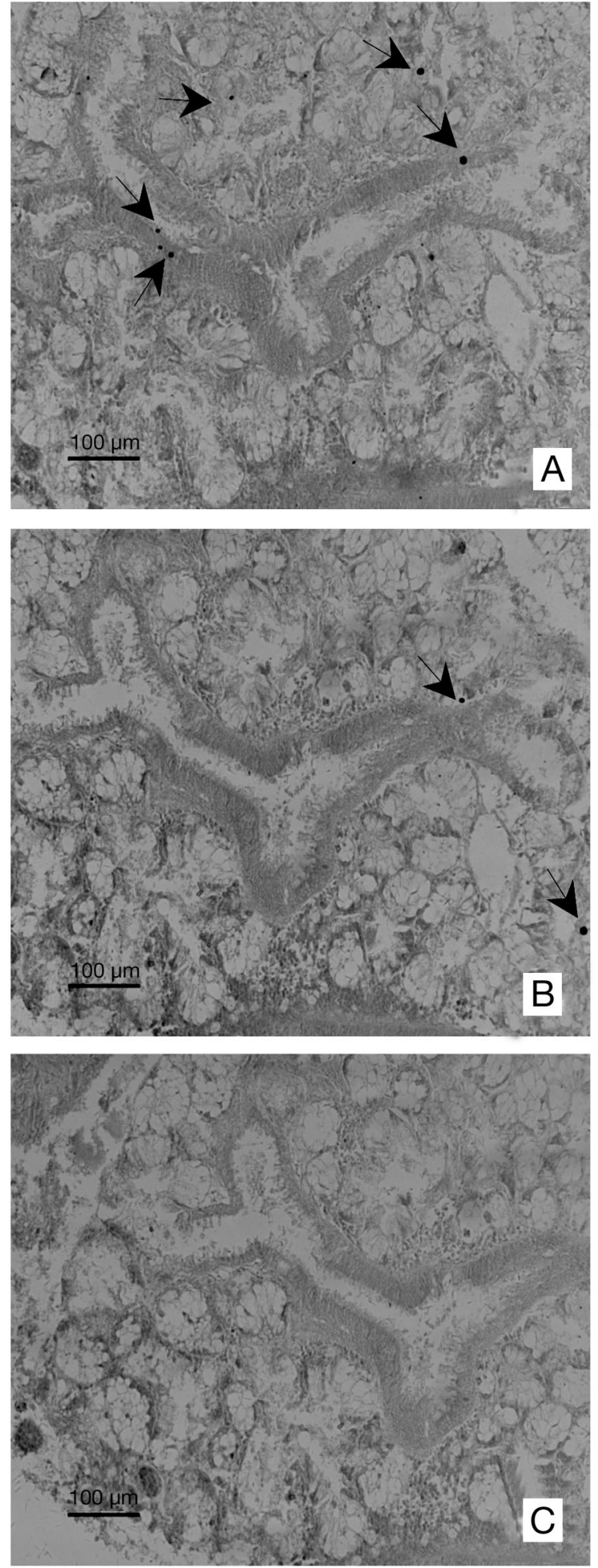

Fig 3. Crassostrea gigas infected by Haplosporidium spp. In situ hybridization (ISH) of sections of Crassostrea gigas digestive gland infected with haplosporidian using (A) Haplosporidium nelsoni-specific probe MSX1347 (arrows) and (B) H. costale-specific probe SSO1318 (arrows), or (C) negative control where no DNA probe was used in the hybridization solution. Scale bar $=100 \mu \mathrm{m}$ 


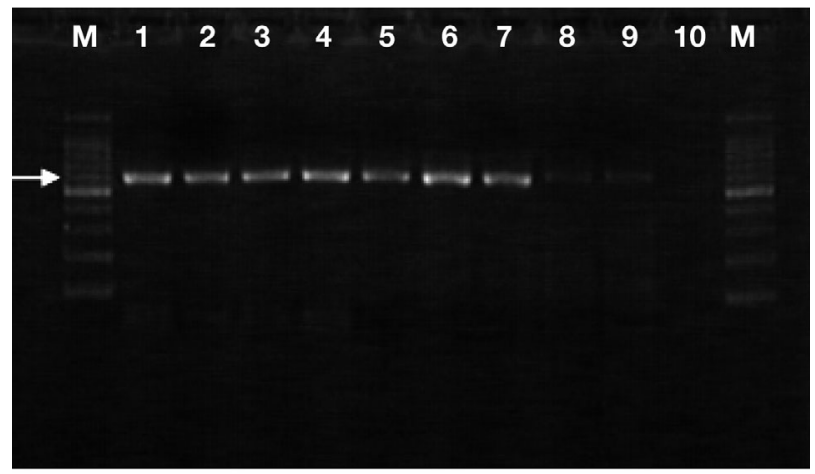

Fig. 4. Gel electrophoresis of polymerase chain reactions (PCR) amplification products of Haplosporidium nelsoni rDNA in oyster Crassostrea gigas. M: 100 bp DNA marker; Lanes 1 to 9: PCR amplification products from tissues of C. gigas collected at Leqing $(1,2)$, Rizhao (3), Rongcheng $(4,5)$, Changdao (6), Laizhou (7), Dongying (8), and Dalian (9), respectively; Lane 10: Negative control containing no template DNA in the PCR reaction. Arrow indicates $600 \mathrm{bp}$

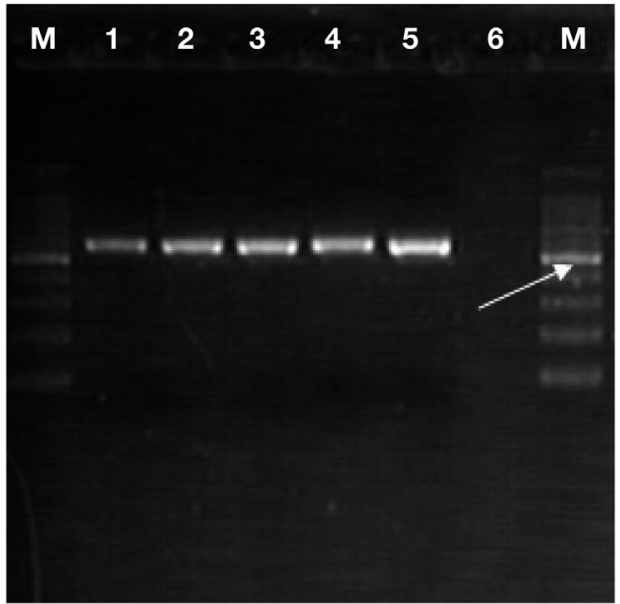

Fig. 5. Gel electrophoresis of PCR amplification products of Haplosporidium costale rDNA in oyster Crassostrea gigas. M: 100 bp DNA marker; Lanes 1 to 5: PCR amplification products from tissues of C. gigas collected at Dalian (1), Dongying (2), Laizhou (3), Changdao (4), and Rizhao (5); Lane 6: Negative control containing no template DNA in the PCR reaction. Arrow indicates $500 \mathrm{bp}$

\section{DISCUSSION}

The results of the present study demonstrate the presence of Haplosporidium nelsoni and $H$. costale in Pacific oysters through histology, PCR, and ISH. In the present study, haplosporidium-like plasmodia were found in Crassostrea gigas from 9 locations, but not in other locations, by histological examination. Identification by ISH and PCR with specific probes and primers indicated the presence of $H$. nelsoni and $H$. costale in these specimens. Andrews \& Castagna (1978) said that no definitive characters have been found with $\mathrm{H} \& \mathrm{E}$ stain to distinguish $H$. nelsoni and $H$. costale. However, we confirmed the presence of $H$. nelsoni plasmodia, because plasmodia hybridized only with the MSX $H$. nelsoni probe in 4 oysters (Table 1). It is difficult to detect $H$. costale through histological examination because of the very rare $H$. costale plasmodia.

Results of PCR and ISH assays supported each other. Plasmodia in Crassostrea gigas samples collected from Rongcheng and Leqing hybridized only with the Haplosporidium nelsoni-specific DNA probe MSX1347, and the sequence of the PCR-amplified DNA was identical to the $H$. nelsoni SSU rDNA target region, with a difference of only 2 nucleotides. Similarly, ISH with SSO1318 probe and sequence of the PCR amplified product with primers SSO-A and SSO-B confirmed the presence of $H$. costale in oysters from Dalian, Dongying, Laizhou, Changdao, and Rizhao.

It should be noted that these 2 parasites are mainly identified in the Bohai Sea and northern coasts of the Yellow Sea, at latitudes between $28^{\circ} \mathrm{N}$ and $40^{\circ} \mathrm{N}$, between January and August. It is thus possible that temperature is a controlling factor for the distribution of haplosporidian species. Further studies are therefore warranted to examine the prevalence of these 2 parasites in summer months in the infected areas. Haplosporidium nelsoni and $H$. costale are usually restricted to high-salinity bays (Andrews 1979, Haskin \& Ford 1982). The salinity in the Bohai Sea varies from 29.0 to 30.0 ppt and from 30.0 to 32.0 ppt in northern coasts of the Yellow Sea. It is possible that these parasites may spread widely on China's coasts in the future because of the high salinity, though the prevalence of haplosporidian species is very low at present.

Crassostrea gigas were imported in the early 1980s from Japan to China and later were cultured in largescale areas along the north coast. The invasion route of Haplosporidium nelsoni and $H$. costale is not clear, and it is possible that these 2 pathogens were originally present in China. Alternatively, these parasites could have been introduced into China via the import of infected oysters and by ballast water. Until now, the presence of these 2 parasites in China had not been reported. Whereas the survey of haplosporidians worldwide (Burreson \& Ford 2004, Reece et al. 2004) is likely incomplete, we are confident that these infections represent $H$. nelsoni and $H$. costale. Further research to study the host-parasite interactions, infection cycle, prevalence, and population structure in both MSX or SSO and oysters is under way.

Acknowledgements. We thank G. Z. Liu et al. for their assistance in collection of oyster samples. This work was supported by the National Natural Science Foundation of China under contract no. 30470275 and the National Special Grant of China under contract no. 908-01-ZH3. 


\section{LITERATURE CITED}

Andrews JD (1979) Oyster diseases in Chesapeake Bay. Mar Fish Rev 41:45-53

Andrews JD, Castagna M (1978) Epizootiology of Minchinia costalis in susceptible oysters in seaside bays of Virginia's eastern shore, 1959-1976. J Invertebr Pathol 32:124-138

Andrews JD, Wood JL, Hoese HD (1962) Oyster mortality studies in Virginia: III. Epizootiology of a disease caused by Haplosporidium costale. J Insect Pathol 4:327-343

Burreson EM, Ford SE (2004) A review of recent information on the Haplosporidia, with special reference to Haplosporidium nelsoni (MSX disease). J Aquat Living Resour 17:499-517

Burreson EM, Stokes NA, Friedman CS (2000) Increased virulence in an introduced pathogen: Haplosporidium nelsoni (MSX) in the eastern oyster, Crassostrea virginica. J Aquat Anim Health 12:1-8

Chu FLE, Burreson EM, Zhang FS, Chew KK (1996) An unidentified haplosporidian parasite of bay scallop Argopecten irradians cultured in the Shandong and Liaoning provinces of China. Dis Aquat Org 25:155-158

Couch J (1967) Concurrent haplosporidian infections of the oyster Crassostrea virginica (Gmelin). J Parasitol 53: 248-253

Friedman CS (1996) Haplosporidian infections of the Pacific oyster Crassostrea gigas (Thunberg), in California and Japan. J Shellfish Res 15:597-600

Haskin HH, Andrews JD (1988) Uncertainties and speculations about the life cycle of the eastern oyster pathogen Haplosporidium nelsoni (MSX). In: Fisher WS (ed) Disease processes in marine bivalve mollusks. Am Fish Soc Spec Publ 18:5-22

Haskin HH, Ford SE (1982) Haplosporidium nelsoni (MSX) on Delaware Bay seed oyster beds: a host-parasite relationship along a salinity gradient. J Invertebr Pathol 40:

Editorial responsibility: Eugene Burreson, Gloucester Point, Virginia, USA
388-405

Haskin HH, Canzonier WJ, Myhre JL (1965) The history of "MSX" on Delaware Bay oyster grounds, 1957-1965. Am Malacol Union Inc Bull 32:20-21

Kamaishi T, Yoshinaga T (2002) Detection of Haplosporidium nelsoni in Pacific oyster Crassostrea gigas in Japan. Fish Pathol 37:193-195

Ko YT, Ford SE, Fong D (1995) Characterization of the small subunit ribosomal RNA gene of the oyster parasite Haplosporidium costale. Mol Mar Biol Biotechnol 4:236-240

Reece KS, Siddall ME, Stokes NA, Burreson EM (2004) Molecular phylogeny of the Haplosporidia based on two independent gene sequences. J Parasitol 90:1111-1112

- Renault T, Stokes NA, Chollet B, Cochennec N, Berthe F, Gérard A, Burreson EM (2000) Haplosporidiosis in the Pacific oyster Crassostrea gigas from the French Atlantic coast. Dis Aquat Org 42:207-214

Stokes NA, Burreson EM (1995) A sensitive and specific DNA probe for the oyster pathogen Haplosporidium nelsoni. Eukaryot Microbiol 42:350-357

Stokes NA, Burreson EM (2001) Differential diagnosis of mixed Haplosporidium costale and Haplosporidium nelsoni infections in the eastern oyster, Crassostrea virginica, using DNA probes. J Shellfish Res 20:207-213

Stokes NA, Siddall ME, Burreson EM (1995) Detection of Haplosporidium nelsoni (Haplosporidia: Haplosporidiidae) in oysters by PCR amplification. Dis Aquat Org 23: $145-152$

Sunila I, Stokes NA, Smolowitz R, Karney RC, Burreson EM (2002) Haplosporidium costale (seaside organism), a parasite of the eastern oyster, is present in Long Island Sound. J Shellfish Res 21:113-118

Wood JL, Andrews JD (1962) Haplosporidium costale (Sporozoa) associated with a disease of Virginia oysters. Science $136: 710-711$

Submitted: October 12, 2009; Accepted: January 6, 2010 Proofs received from author(s): March 26, 2010 